\title{
The Pagan King Replies: An Indian Perspective on the Portuguese Arrival in India
}

\author{
SEBASTIA N R. PR A NGE* \\ E-mail: s.prange@ubc.ca
}

This article recommends a virtually unknown manuscript on the early Portuguese presence in India to wider scholarly attention. Dubbed here the Wye manuscript, this text purports to be an English translation of a sixteenth-century Malayalam history that was produced at the court of the ruler of Calicut. The South Indian kingdom of Calicut was central to Portugal's project of monopolizing the region's all-important pepper trade; the Wye manuscript therefore holds the promise of adding an Indian perspective to a history that has been written largely on the basis of European sources. This article examines the external and internal evidence for the author's claim of having translated the text from an original palm-leaf manuscript held by members of Calicut's royal family. An analysis of its content shows significant overlap with an Arabic history of the sixteenth century; a comparison of their similarities and differences suggests a number of insights into the processes of composition and revision of both the Malayalam and Arabic texts. Last, and most important, the Wye manuscript is transcribed in full in the hope of stimulating further discussion and study.

Keywords: India, Malabar Coast, Portugal, historiography, primary sources, manuscript cultures.

Brave GAMA spake; the pagan king replies,

"From lands which now behold the morning rise,

While eve's dim clouds the Indian sky enfold,

Glorious to us an offer'd league we hold.

Yet shall our will in silence rest unknown,

Till what your land, and who the king you own,

Our council deeply weigh."

— Luís Vaz de Camões, The Lusíads ${ }^{1}$

The arrival of the first Portuguese fleet in the Indian Ocean is generally regarded as a watershed moment in world history, comparable in its significance only to Columbus' discovery of the Americas. Although historians have long sought to qualify the 
notion of a "Vasco da Gama epoch of Asian history" by pointing to the limits of Portuguese power in the Indian Ocean and to the long-term continuities in the patterns of trade and power relations, the sense that 1498 marks a decisive break in the history of maritime Asia continues to inform both scholarship and textbooks. ${ }^{2}$ Yet, despite the fact that Vasco da Gama's voyage and its aftermath are seen as transformational not just for Europe but also for Asia, and especially so for the Indian subcontinent, the historiography of these events is characterized by an inherently European perspective. This holds true not only of studies that explicitly focus on European themes and European actors-along the lines of research questions such as "Did Vasco da Gama matter for European markets?"-but even for efforts to write history from an Indian perspective. ${ }^{3}$

The challenge lies in recovering Indian voices from European sources amidst a comparative "silence of Indian records on the whole presence of the Portuguese" in India. ${ }^{4}$ Consequently, histories of the early Portuguese presence in India are inevitably based on European archives containing materials produced by Portuguese officials, traders, and missionaries. ${ }^{5}$ Many of these sources are highly problematic as they view India through the lens of European ambitions, preoccupations, and prejudices. In the image drawn from Camões' Os Lusíadas (1572), the epic poem celebrating Portugal's imperial project, it is Vasco da Gama who speaks in the historical record; even the purported response by the "pagan king"-that is, by the local Hindu ruler - is put into his mouth by the Portuguese poet.

Since at least the reign of John II (r. 1481-95), Portugal's programme of maritime exploration was animated primarily by the desire to reach the Indian Ocean. By the time that Vasco da Gama achieved this feat by rounding the southern tip of Africa in December 1497, his destination had become more specific. In the words of his anonymous chronicler, the fleet's target was "a city called Calicut, on which the king had information." At the turn of the sixteenth century, Calicut (Malayal. Kozhikode, Ar. Qāliqūt or Kālikūt) was one the greatest entrepôts in all of monsoon Asia and the pre-eminent port city on the Malabar Coast. ${ }^{7}$ This region, on the southwestern edge of the Indian subcontinent, was known to foreigners as the "land of pepper" on account of its near-monopoly on the cultivation of the most important ingredient of the Indian Ocean spice trade, black pepper. ${ }^{8}$ Malabar, therefore, was key to the Portuguese goal of monopolising the pepper trade; as a consequence, this region, and the kingdom of Calicut in particular, became the "major test case" of Portugal's imperial project in maritime Asia. ${ }^{9}$

The sources through which historians strive to reconstruct this momentous period, however, are irregular, desultory, and problematic. Vasco da Gama's supposedly epoch-making first steps on Indian soil, for example, are recorded solely in an anonymous Portuguese journal; likewise, the subsequent decades of trade, politicking, and conflict on the Malabar Coast are known almost exclusively through European sources. ${ }^{10}$ It is therefore not surprising that a rare exception to this overall pattern-Zayn al-Dīn al-Malabarī’s Tuhfat al-Mujāhidīn, a sixteenth-century Arabic text written by a Muslim from the Malabar Coast-has received enthusiastic 
attention from historians eager for an alternative vantage point from which to view this crucial period of Portuguese expansion and consolidation on the Indian coast. ${ }^{11}$

Zayn al-Dīn's account reflects the perspective and priorities of Malabar's Muslim elite, who were at the sharp end of Portugal's attempts to wrest control of the profitable spice trade out of their hands. However, because of this text's intended audience - it is addressed to Muslim rulers and dedicated to the sultan of Bijapur, 'Alī 'Adīl Shāh — and its stated aim of enlisting these rulers to join Malabar's Muslims in a common jihad against "the Franks" [al-franj], its recounting of the Portuguese presence on the Malabar Coast is inevitably coloured by this agenda. This tendency within the text is most acute in Zayn al-Dīn's description of events in the latter half of the sixteenth century, when the hereditary rulers of Calicut, known as the Zamorins, entered into a series of treaty relationships with the Portuguese, to the detriment of the local Muslims. Thus, by its very conception and purpose, Tuhfat al-mujāhidīn is at a remove from the region and society it describes; as vital a source as it is, it can only offer limited insights into the actions and attitudes of Malabar's political elite. In this record too, then, the words and motives of the Hindu sovereign are once more attributed to him by others.

The absence of an Indian perspective in the historical record for this period, that is of sources that reflect the outlook and attitudes of South Indian rulers, has often been attributed to a general lack of interest in history within Indian society. As early as the eleventh century, the Persian historian al-Bīrūnī claimed that "the Hindus do not pay much attention to the historical order of things." ${ }^{12}$ Modern scholars similarly assert that in India, "there is a remarkable dearth of historical writing in the period before the Muslim conquest and an associated indifference to historiography." 13 This problematic claim - problematic above all because it posits the development of a particular genre of historical consciousness as it developed in European societies as the only valid expression of knowledge about the past - is being challenged in recent scholarship that raises new questions about the evolution and uses of narrative forms of history in premodern South India. ${ }^{14}$

Leaving aside ongoing philosophical debates about differing conceptions of what constitutes historical truth, the underlying charge that an Indian indifference to chronological history - to "the historical order of things," in al-Bīrūnī's phrasemust be rejected. Evidence for the Malabar Coast shows a very deliberate and highly organized effort by local rulers to collect and preserve the records and chronicles of their kingdoms. Visitors to Calicut regularly commented on the astounding diligence with which royal officials recorded the affairs of the kingdom. Duarte Barbosa, who himself served as a scribe (escrivão de feitor) to Portugal's Estado da Índia, observed his local counterparts in the early years of the sixteenth century: "The king of Calicut constantly has in his palaces many writers...; they record everything concerning the affairs of the king, about the stipends he gives to the Nair soldiers, about people who go before him with complaints, and about the accounts of his tax collectors." 15

A century later, François Pyrard de Laval formed a similar impression of the kingdom's record-keeping. As a Frenchman, he was welcomed as a common enemy 
of the Portuguese, and thus able to closely observe how archives continued to be produced and maintained in this manner across the region:

There is another set of buildings [at the palace] dedicated to the secretary and scribe of the king, and for keeping all the registers, which is truly admirable; and I am continually surprised to see a large number of men who have no other responsibility and do nothing else the whole day than to write and register.... Some of them write about the merchandise that arrives for the king; others, about the dues and taxes that are paid daily; others, about the expenditure of the royal household; others, about the day's most notable events, as much within the court as within the rest of the kingdom; in short, all the news.... The king has these same scribes in each of the towns, ports, harbours, and entryways of his kingdom, who provide their reports to the palace, and all of this proceeds with order, each obeying one another and each having their own supervisors [supérieurs]. Throughout the whole Malabar Coast exists the same manner of writing and the same organization. ${ }^{16}$

These tantalising descriptions hint at the magnitude of the archive that has been lost. Rather than attributing it to a supposed indifference to history, the dearth of South Indian sources must thus be attributed to the vicissitudes of time and the ravages of man. Internecine conflicts, Portuguese bombardments, and later invasions all contributed to the loss of records kept in palaces, customs houses, and temples throughout the region. ${ }^{17}$

Another factor in the paucity of local sources is the nature of writing material used. Paper was not produced, or even available, locally. This is evident, for example, from the special efforts Jewish and Muslim merchants based in South India made to have sheets of paper shipped to them, so that they could use them for their correspondence and other writing needs. ${ }^{18}$ Instead of paper, local scribes used the leaves of palm trees (of both the Palmyra and Talipot varieties). Many visitors commented on this practice, among them Duarte Barbosa and Pyrard de Laval:

Everything is written on the long, flattened leaves of palm trees [folhas de palmeiras bravas]; they write without ink, using instead a tip of iron that makes marks with their handwriting, which is like ours and in straight lines. ${ }^{19}$

They write with iron styli [poinçons] on palm leaves, which are yellow, very thick, and durable.... It is a remarkable thing to observe their [the scribes'] numbers and the fine organization that exists between them, and how quickly they write on the palm leaves, which are of the length and width of those of the coconut tree, but thick and harder. They make with them a sort of book with a hole at the thicker end of the leaves through which they pass a string that binds together as many as they wish. ${ }^{20}$

Such bound palm-leaf manuscripts are widely known as common writing materials from South and Southeast Asia. Even though palm leaves often proved more durable than paper (one extant palm-leaf manuscript from Nepal dates from the ninth century), the South Indian climate with its seasonal high humidity and heat meant that the preservation of these media still required the cyclical copying from decaying materials to new ones. When these cycles came to be interrupted due to political upheaval or dynastic change, entire archives could be - and clearly have been-lost. ${ }^{21}$ 
It is against this background that the significance of a manuscript that has not yet entered the scholarly discourse must be assessed. Housed at the British Library, this text purports to relate the history of the early Portuguese presence on the Malabar Coast from an Indian perspective. It has remained almost entirely unknown to historians and has not been used in any of the major studies of the history of the sixteenth-century Malabar Coast. ${ }^{22}$ This article seeks to recommend this manuscript to wider scholarly attention by examining the external and internal evidence for its authenticity. It argues that it offers an additional perspective on the events of the sixteenth century and as such forms an important addition to known sources in Portuguese, Arabic, and Malayalam.

The manuscript in question is entitled "A Translation of a History of the Portuguese Landing in India, written on the leaves of the Brab tree (called Ola) in the Malabar language." 23 The bound volume consists in fact of two manuscripts: the first (hereafter $\mathrm{MS}_{1}$ ) is densely written on both sides of the folios, while the second $\left(\mathrm{MS}_{2}\right)$ is a transcript of $\mathrm{MS}_{1}$ on single sides only. Physical examination of the manuscript shows that the paper of $\mathrm{MS}_{2}$ bears the watermark of Portal \& Co with the year 1798, which corresponds to other products of this Hampshire paper mill, a favourite of British officialdom, from this period. ${ }^{24}$ In terms of content, there are a few minor discrepancies between the two manuscripts, mostly in the transliteration of Malayalam words, some of which have been corrected in pencil in $\mathrm{MS}_{2}$. Both versions contain a colophon that states that the original manuscript in "the Malabari language" was presented by "the Venkatycotta $\left[\mathrm{MS}_{2}\right.$ : Vencaticota] Raja who is of the Tamuri family" to John William Wye, who completed his translation on 19 August 1800. $\mathrm{MS}_{2}$ contains an additional final note stating that it was copied for the library of the English East India Company. This version of the manuscript also contains a footnote that correlates a year of the Malayalam calendar to the year $1804 \mathrm{CE}$, which suggests that this second copy was prepared a few years later than the original translation of $\mathrm{MS}_{1}$; it is not clear whether the corrections marked in pencil were made by the original translator or someone else. The Wye manuscript thus purports to be the translation of an older, Malayalam history owned by the royal family of Venkatakotta (modern Kottakal in Kerala), who were related to the dynasty of the Zamorins, the hereditary rulers of the kingdom of Calicut.

John William Wye can be traced as an employee of the English East India Company. In early 1792, he was appointed assistant surgeon to the Bombay Presidency and posted to Malabar. ${ }^{25}$ In 1795 , he is listed on a credit note between the Company and a minor Kerala prince as the document's "Malayalam Translator."26 The next year, he is named in an official despatch as one of the few officers to have achieved "considerable proficiency" in the notoriously difficult Malayalam language. ${ }^{27}$ In 1804, Wye was once again officially recommended for "his knowledge of Malabar affairs." ${ }^{28}$ East India Company records thus make it possible to ascertain that Wye was capable of translating a Malayalam document into English.

Crucially, additional documentation of his activities in Malabar also shows that he was regularly in close contact with local elites, which would have made it possible for 
him to access their historical records of the kind his manuscript is supposedly based on. ${ }^{29}$ The Scottish botanist Francis Buchanan (later known as Francis Hamilton) met Wye on his travels in Kerala in December 1800; he records that Wye was acting as the collector for four districts, a function that rendered him the primary intermediary between the colonial state and local rulers. ${ }^{30}$ Wye's roles as both a collector as well as a translator in high-level negotiations thus brought him into regular close contact with Malabar's royal families. ${ }^{31}$

Remarkably, he is also reported as having saved the life of the hereditary ruler of Calicut, the Zamorin. In early 1793, shortly after his arrival in India, a faction of the royal family attempted to assassinate the Zamorin; though severely wounded, he is recorded to have "recovered under the treatment of Surgeon Wye." 32 It is not a stretch to imagine that this event made Wye a known and favoured person at court and allowed him to gain entrée into its archives, such as they were at the time. What little is known about Wye's life from official records thus substantiates that he had the opportunity to obtain a manuscript from one of Malabar's royal families as well as the ability to read and translate it.

Wye's rubric to his translation states that the original was a palm-leaf manuscript (using the Malayalam term ola) written on leaves of the Brab tree (Borassus flabellifer, or Palmyra palm), a common source of writing material. This original document appears to have been in the form of a traditional granthavari. Granthavaris (a term derived from either the ancient Grantha script, on which Malayalam is based, or the original Sanskrit meaning of grantha, "book") were the dominant genre of historical writing favoured by Kerala's Brahmins. There are a number of extant historical granthavaris of different provenance and period, few of which have been published. Most of these are temple records, dealing with the land titles and legal rights of important temple establishments, rather than palace records that would incorporate the kind of information that Duarte Barbosa and Pyrard de Laval described as being gathered daily at the royal court. ${ }^{33}$ A collection of palace records is extant at the Vallathol Vidyapeetham in Edapal, which includes palm-leaf manuscripts, but their chronology is uncertain. ${ }^{34}$ A particularly comprehensive palace granthavari stemming from the ruling house of Cochin has been published by the Kerala State Archives; lamentably, it contains almost no information on the sixteenth century at all, with any kind of detailed account commencing only with the period of the rise of Dutch power in the region during the second half of the seventeenth century. ${ }^{35}$ All this means that a granthavari dealing in detail with events of the sixteenth century, during the period of Portuguese expansion on the coast, must be regarded as a true addition to the known historical record, all the more so if it reflects the view from Calicut, which was central to Portuguese ambitions and developed into a hub of anti-Portuguese resistance.

Another Malayalam source against which the Wye manuscript must be situated is known as the Keralolpatti. It forms the most comprehensive collection of narratives about Kerala's past as viewed through the historical consciousness of the Brahminical elite; it may be regarded as a sort of archetypical granthavari of Kerala. The Keralolpatti offers an account of the region's history from the creation of the land by 
Vishnu's avatar Parasurama, with a strong focus on the reign of the medieval Chera Perumals and the affairs of the local Brahmins. Scholars have treated the Keralolpatti in different ways, some dismissing it altogether as a "farrago of legendary nonsense" while others advocate for it "not to be rejected outright, but used with caution." 36 The Keralolpatti does not exist as a single text but is extant in many different recensions that reflect their period of writing as much as their royal patrons, with the earliest manuscripts dating from the seventeenth century. ${ }^{37}$ The best-known version of the Keralolpatti, which has been the basis for most scholarly work, ends with the coming of the Portuguese. ${ }^{38}$ The Wye manuscript could thus be seen as an extension to the traditional Keralolpatti, bringing it up to date with the momentous events set in motion by Vasco da Gama's landing on Indian soil.

However, the text of the Wye manuscript also shows significant differences to the Keralolpatti in terms of both narrative and form. For one, it does not begin with the Parasurama legend, the foundational myth of Kerala's Brahmins. Rather, it opens with the story of Cheraman Perumal, a legendary king of the Chera dynasty who is said to have surrendered his throne and divided his kingdom before converting to Islam. The account of the Cheraman Perumal tradition as recounted in the Wye manuscript tallies with Arabic versions of this story, although it does not contain the same level of detail as those Arabic manuscripts. ${ }^{39}$ Calicut is without doubt the main focus of the Wye manuscript, and the recounting of the Cheraman Perumal legend reflects this: it puts special emphasis on the singular role that the abdicating Cheraman Perumal bestowed on the Zamorin, and the subsequent rise of his kingdom to pre-eminence as a result of this special mandate from the last Chera king.

In contrast to the Keralolpatti, the main body of the granthavari translated by Wye is an account of the diplomatic and military encounters with the Portuguese. This temporal focus sets it apart from other Malayalam granthavaris, including the Keralolpatti, which mostly concern themselves with the legends and stories of a much earlier period, as well as from the Cochin palace records that chiefly deal with the later Dutch period. The chronological framing of the Wye manuscript does, however, correspond closely to that of the Arabic Tuhfat al-mujähidīn. The close correspondence between these two texts goes beyond a shared chronology: there is also significant overlap in the content related for the period after the coming of the Portuguese. This agreement extends even to specific details such as the precise dates of events (rendered in both texts according to the Malayalam as well as Islamic calendars), the number of soldiers killed in particular battles, and the personal motivations ascribed to various actors. This is to say that in large part, the Malayalam and Arabic texts appear closely related if not identical.

At the same time, there are also telling differences. Most notably, Tuhfat al-mujāhidīn contains extensive descriptions of events outside the Malabar Coast. For example, it has lengthy sections on the battle of Diu (1509), in which the Portuguese repelled an attack by a combined fleet of Gujarat and Egypt (with support from other states), the Portuguese conquest of Goa (1510), and Portugal's abortive attacks on Aden and Jeddah (1513). Similarly, passages about the various humiliations and 
degradations suffered by Malabari Muslims at the hands of the Portuguese are not found in the Wye manuscript, nor are accounts of the martyrdom attained by heroic Muslim fighters. So, while the overall political history recounted in the two texts is congruent, they do not share the same perspective when it comes to the affairs of Malabar's Muslim communities or even the same basic information about events occurring beyond the Malabar Coast.

Another way in which the two texts largely coincide yet differ in detail is in their chronologies. The narratives of both texts begin in the pre-Portuguese period, deal in great detail with the years from 1498 to 1531, and then provide cursory information for the subsequent half century. This inconsistent structure, which gives such prominence to the first three decades of the Portuguese presence in India but only scant attention to the more recent history, is especially baffling in the case of Tuhfat al-mujähidinn, which had as its immediate aim to compel Muslim rulers to take action against the Portuguese. Despite its widespread use as a primary source for the Portuguese expansion in Asia, this anomaly in the Arabic text has not been accounted for by historians; it could be explained, however, by its relationship to the text that was translated by John Wye more than two centuries later.

Zayn al-Dīn al-Malabarī was born around 1532 in Ponnani, Kerala. Several of his writings are extant, including two legal texts (Fath al-mu'ìn and Qurrat al-'ayn), but he is best known for his historical Tuhfat al-mujāhidin, which is generally dated to the $1580 \mathrm{~s} .{ }^{40}$ His purpose in writing this book was political and urgent: he wanted to persuade rulers in other parts of the Islamic world to come to the aid of the Muslims of the Malabar Coast, who after eight decades of Portuguese aggression were in dire straits. This objective is made explicit in the text: "I have compiled this account to inspire the faithful to undertake a jihad against the worshippers of the cross. ${ }^{, 41}$ A recurring theme of Tuhfat al-mujāhidīn is how the jealousies, secular ambitions, and feuds among Muslim rulers have so far prevented a concerted effort to resist the European oppressors: "The Muslim sultans and emirs - may Allah heighten the glory of the helpful among them - did not take any interest in the affairs of the Muslims of Malabar, although jihad is an obligatory duty upon them." 42

Yet, despite the book's express aim of compelling Muslim rulers in other parts of India and the Middle East to come to the aid of their Malabari brethren, most of the historical narrative deals with the period between the arrival of the Portuguese in 1498 and the year 1531. This focus on events that happened half a century or more before Zayn al-Dīn's wrote his book is peculiar: it neither corresponds to Zayn al-Dīn's own lifetime, nor does it seem to bolster his aim of demonstrating a pressing need for military assistance in the 1580s. There is no question that his historical account of how Portuguese power on the Indian coast evolved over time supports his overall argument. But the fact that the narrative more or less ends in the 1530s, with only desultory attempts to describe more recent events, seems to go against the primary purpose of his writing, which is to incite Muslim rulers to immediate action. His decision to focus his book on this much earlier period is all the more curious because, as is amply demonstrated by the Portuguese' own sources, in the decades 
since there was certainly no shortage of anti-Muslim acts of aggression that he could have reported to bolster his case.

This otherwise unaccountable chronological focus of Tuhfat al-mujāhidīn does, however, correspond closely to that of the Wye manuscript. The main narrative of both texts concludes with the construction of the Portuguese fortress at Chaliyam in about 1531. Descriptions of a few subsequent events bring the narrative up to the late sixteenth century, but these are appended in an annalistic style that is at odds with the preceding prose. This internal inconsistency could result from the fact that the events for the years between 1531 and the 1580s (1590s for the Wye manuscript) were added to the original narrative at a later date. This would explain why the two texts diverge from one another most clearly in their descriptions of those later decades: whereas they shared a common source of information for the construction of the main narrative (which, again, covers a period of time before the only known author, Zayn al-Dīn, was even born), their addenda were derived independently of one another, from different sources.

Close reading of both texts strengthens this impression that the much more complete, coherent, and consistent narrative for the period from the first arrival of the Portuguese up to 1531 is of a different source than the annalistic entries that briefly summarize a few key events for the next five decades. In the case of Tuhfat al-mujahidin, however, there is additional evidence to support this hypothesis. As previously noted, Zayn al-Dīn dedicated his text to 'Alī 'Ādil Shāh, the sultan of Bijapur. The lavish, florid dedication to this Deccani ruler is written in the present tense and leaves the reader in no doubt that the sultan was still very much alive and in power at the time of writing ("he is a noble sovereign"; "may he subdue the impious"; "may Allāh grant perpetuity to his kindness"; etc.). ${ }^{43}$ Yet, as is well documented, 'Alī 'Ādil Shāh's reign ended with his death in $1580 .{ }^{44}$ Most scholars have dated Tuhfat al-mujāhidin to 1583 , for the simple reason that this is the last date mentioned in the text. (In fact, the text is uncharacteristically vague about the last events it describes, situating them in the trading season (mawsim) of either 990 or 991 АH.) ${ }^{45}$ By contrast, the book's dedication to 'Alī 'Ādil Shāh in terms that strongly imply that it was written within his lifetime suggests that Tuhfat al-mujähidīn was first composed (and likely presented to the ruler of Bijapur) before the sultan's demise in 1580. The description of events occurring after 1580 must have been added later, and the marked stylistic disparities suggest that this was in fact the case for all of the entries that cover events after 1531 .

This conjecture prompts the question of why Zayn al-Dīn would have ended his historical account of the Portuguese arrival on the Malabar Coast with the events of 1531. The answer may well lie in the special significance of the Portuguese fortress at Chaliyam, the construction of which in 1531 marks the end of the book's primary narrative. Chaliyam fort plays a major role in the history of the sixteenth-century Malabar Coast, and especially in the history of the kingdom of Calicut. For the forty years of its existence, this fortified Portuguese outpost was "a thorn in the Zamorin's side" because it allowed the Portuguese to put an effective stranglehold on all of Calicut's sea trade with the south. ${ }^{46}$ A number of pitched battles were fought over it 
before it was finally subdued in 1571 after an assault that incurred great loss of life among a combined force of Hindu and Muslim attackers. In the estimate of K. M. Panikkar, the destruction of Chaliyam fort represented the effective end of the Portuguese effort to suppress Calicut's maritime trade: "Seventy years of conflict had come to nothing, and the victory in this prolonged conflict lay decisively with the Ruler of Calicut." ${ }^{, 77}$ By ending his account of the rise of Portuguese power with the construction of Chaliyam fort, Zayn al-Dīn drew on a well-known and still-resonant symbol of European ambition and hubris.

Although the Wye manuscript carries its own chronology further than that of Tuhfat al-mujāhidīn (up to the year 1589/90, instead of 1583), it mirrors its stylistic rupture after 1531 , with subsequent entries marked by the same uncharacteristic annalistic brevity. This is perhaps best exemplified by the nonchalance with which the crucial victory of the forces of the Zamorin at Chaliyam is recorded. Clearly, the defeat of the Portuguese at Chaliyam and the destruction of their fortress there was an event of immense importance to the kingdom. And yet, while the events leading up to the construction of the fort in 1531 are described in great detail (including even the provenance of the stones used in its construction), the Zamorin's eventual victory over it is related only by a single line: "In $979 \mathrm{~T}$. or 747 M.S. [=1571] the Tamoory [Zamorin] took the fort at Chaliutt from the Fringies." ${ }^{48}$ The terseness with which this historic event is noted strengthens the impression that it was added to the main narrative at a later date, perhaps during the copying of the deteriorating original palm-leaf manuscript.

Adding to, subtracting from, or otherwise revising texts was of course common practice in the manuscript cultures of both the Arabic and South Indian literary traditions. The two texts, Zayn al-Dīn's history and the granthavari translated by Wye, closely match one another in their main narrative that covers the years 1498 to 1531, while they diverge in their much briefer accounts of the subsequent decades (with the Wye manuscript covering a few more years than the Arabic text). In light of the stylistic ruptures found within both texts, as well as the evidence of the anachronistic dedication in Tuhfat al-mujähidīn, it is likely that both texts were appended after their original composition, by different scribes who were working independently of one another with the Arabic and Malayalam urtexts of the sources extant today.

These variances between Zayn al-Dīn's Arabic history and Wye's translation of a Malayalam granthavari offer important clues to their composition and copying, but as significant as their differences are the similarities between the two texts. The pronounced parallels between their main narratives for the years 1498 to 1531 make the conclusion that these texts are interrelated virtually inescapable. The only question is in what direction this relationship runs. Even if, contrary to the evidence presented above, the date of composition for the original granthavari later translated by Wye is assumed to lie in the 1590s (and not in the 1530s, as seems more probable from its content, with a brief section on the subsequent decades appended at a later date), the case for it being a direct translation of Tuhfat al-mujähidin is not straightforward. One would have to presume that the author(s) of the granthavari not only had access to Zayn al-Dīn's relatively recent work, which was finished only a few 
years earlier, and perhaps not in Kerala at all but at the court of Bijapur in the Deccan, but also the ability to read its stylized Arabic prose. The notion that the Malayalam text is a copy of Zayn al-Dīn's manuscript is also called into question by the treatment of certain Malayalam terms within the Arabic text. For example, in the Wye manuscript, one of the Zamorin's ministers is denoted as Eliatha (or Elayadu), which corresponds to elayathu, a commonly used Malayalam word for "younger one"; this minister was likely a junior relation of the Zamorin. ${ }^{49}$ In the Arabic text, this term is rendered as the name "al-Yadh." 50 This mistake of confusing a descriptive designator ("younger one") for a personal name (rendered in the style of an Arabic nisba as "al-Yadh") is easy enough to reconstruct under the assumption of a Malayalam-toArabic translation, whereas it becomes nonsensical in the reverse. While the possibility that the Wye manuscript is based on a straightforward Malayalam translation of Zayn al-Dīn's Arabic history cannot be altogether dismissed, such lopsided corruptions suggest that the relationship between the two texts is more complex - and more intriguing. ${ }^{51}$

On balance, it seems probable that both texts drew on a store of popular accounts of the construction of Chaliyam fort. These same stories appear to have also provided the basis for Muhammad al-Kālīkūtī's epic poem al-Fath al-mubīn li'l-sāmurī alladhī juhibb almuslimin ("The complete victory of the Zamorin who loves the Muslims"), which dates from about the same period. ${ }^{52}$ It is tempting to speculate, although impossible to ascertain, that the composer of the granthavari on which the Wye manuscript is based, who in all likelihood was a Brahmin, had a Muslim informant or perhaps even collaborator. Such a situation is not that difficult to imagine given the hybrid composition of the Zamorin's court in the later sixteenth century, by which time Muslims had acquired a high degree of political influence due to their key role in fighting the Portuguese at sea. ${ }^{53}$

In light of the external and internal evidence summarized here, it is argued that the Wye manuscript represents a chronicle in the traditional format of a granthavari that was prepared for the ruling house of Calicut. It was likely first prepared after 1531 and expanded, in a more annalistic fashion, in the 1590s. Its description of the early activities of the Portuguese, and especially of their acts of hostility against Malabar's Muslim merchants, drew heavily on information current among the Muslim community at Chaliyam. This same information was utilized by local authors writing in Arabic during the 1580s, notably Zayn al-Dīn al-Malabarī and Muhammad al-Kālīkūtī.

As for John William Wye, it can be shown that he had the ability to translate a Malayalam palm-leaf manuscript and the connections to gain access to it. His claim to have received the manuscript from a relative of the Zamorin is plausible: Wye's standing with the royal family must have been rather favourable after he saved the life of the Zamorin in the 1790s. Company records testify to Wye's prolonged residence in Malabar and his command of Malayalam, which would have enabled him to recognise the significance of this manuscript and to render it into English. The text's general focus on Calicut, its description of the legendary origins of its ruling dynasty, and its favourable depiction of Muslims - who had long occupied a prominent position in the kingdom's economy, and in the sixteenth-century played a crucial role in its struggle against the Portuguese - all support the notion that the manuscript was prepared for the 
Zamorins of Calicut, along with all manner of records and accounts that an extensive and highly organized system of writers continually produced on behalf of the palace.

The Wye manuscript is transcribed here in the hope that scholars familiar with additional Malayalam granthavaris will be able to situate it more firmly within that literary tradition. Its very existence also throws new light on Tuhfat al-mujāhidīn, which is generally regarded as the single most important non-European source for the history of South India during those critical early decades of the Portuguese presence on the Indian coast. Although it does not revise the outline of that history, since it shares the account known from Zayn al-Dīn's Arabic text in almost all details, its presence in the Zamorins' archives hints at the significance this account was accorded not only among Muslims but also within the highest echelons of Hindu society. In this sense, it affords, pace Camões, a distant echo of the pagan king speaking at last.

Wye's translation is presented below with minimal editorial intervention. As has been established for Tuhfat al-mujähidīn, its content corresponds to what is known from contemporary Portuguese sources. ${ }^{54}$ Unless offset in square brackets, all notes are Wye's; emphases in the text follow the original. Corrections made on the manuscript in pencil have been adopted into the text. Inconsistencies in the spelling of Malayalam words (e.g. "Tamuri" and "Tamoory") have been retained. Folio pagination and editorial comments are noted in square brackets. fols. $21 r .-37 r$.

\section{Translation of a History of the Portuguese landing in India written on the leaves of the Brab tree (called Ola) in the Malabar} language

When the Emperor Perumal was about to depart for Mecca, he gave the whole country of Malabar in shares to the different Rajas, at which period the Tamuri ${ }^{1}$ [Zamorin] was at some distance, \& that was the reason of his not having a country given him; the Tamuri Raja after this came back, Perumal gave his seal, and sword to

\footnotetext{
${ }^{1}$ The mode in which the Malabars write the official title of their Raja which Europeans spell Zamorin.
} 
him, telling the Tamuri he must conquer countries and retain them by that sword, accordingly in a short time the Tamuri Raja employed himself diligently to do as Perumal ordered him, and he got the country of Korikote ${ }^{2}$ [Malayal. Kozhikode, angl. Calicut]. - At this time the people of the tribe of Islam came to see the Raja, took up their residence at Korikote, and from divers countries, merchants and tradespeople came; $\&$ by exercising their respective callings, [22r.] Korikote began to grow a large place; throughout the whole of Malabar, the city of Korikote was the first in rank after this, the tribe of Islam came from several places, and assembled together by which the Tamuri became the most powerful, \& the principal among the Rajahs of Malabar; of whom some were possessed of strength and some were not In this period none of the Rajahs passed each others boundaries, which was agreeable to the orders of the Perumal at his departure; their kingdoms extended some one Kathum $^{3}$ and some more - Some of them had 100 Men, some 200, some 300, some 1000, some 5000, some 10,000; some 100,000; and some had still more - In some countries there were two Rajahs, in some three and in others even more: in the countries that had two Rajahs if one was more powerful than the other, he would not quarrel with, and trespass in the others boundaries: if any did quarrel, he would get no one to assist him - Amongst these Rajahs the one who had most men governed the country from Tekè $^{4}$ Kollam $^{5}$ to [23r.] Kaniakumary ${ }^{6}$ : at this time his name was Tirnpathy $^{7}$; the next Rajah reigned over Màdy Walaputnam, around Kannanoor, Edèkaât, and Darmapooram, he was called the Kolatirry ${ }^{8}$ Rajah; but amongst these Rajahs in point of Dignity, power and consideration in foreign countries, the Tamoory was pre-eminent; and amidst all the remaining Rajahs in Malabar, in honors, and Dignities the Tamoory stood first; the reason of this was the gift of the seal and sword by the Emperor Perumal, who himself reposed confidence in the tribe of Islam, after whose departure they came and settled in the country, put trust in the Tamoory, and on account of this friendship strangers came from other countries with shipping people, whom the Rajah received honourably, and sent them away in a friendly manner - When the Rajah went to any place either for war; or any other affair of consequence, the [24r.] sword was carried before him as formerly before Perumal - If any circumstance occasioned a war between the Tamoory, and any other of the Malabar Rajahs, and they gave him either money, or country and sued for peace, then he retired quietly and left them; but if any of the Rajahs neither gave money or country, he then would not cause his army to commit devastation,

\footnotetext{
${ }^{2}$ Spelt and called by Europeans Calicut.

${ }^{3}$ Commonly spelt $\operatorname{Cof} s$ a distance of 4 Miles.

${ }^{4}$ Tekè is South.

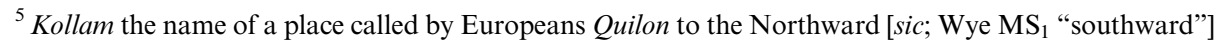
of Cochin.

${ }^{6}$ Kaniakumary is Cape Comorin.

${ }^{7}$ The official name of the Travancore Rajah's Sircar is Tirnpasaaron taken probably from Tirnpathy.

${ }^{8}$ Kolatirry is called by Europeans Kolastry, the word is derived from Kola, a thin piece of stick, \& tirry, cotton when wound round it to form the wick of a lamp.
} 
but remained for a length of time upon the borders of that country, till he was satisfied; such was the ancient Custom, nor could he act in any other manner: but if quarrels, and wars arose among the other Rajahs of Malabar they slaughtered each other, and ruined each other's country - The History of the Fringie's ${ }^{9}$ coming into Malabar. In the year of the Talika ${ }^{10} 904$ or the $6^{\text {th }}$ of Karkadom $672^{11}$ three of the Fringies ships came to Pandaranykollam ${ }^{12}$, it being in the Monsoon they anchored there, and came on shore, they went to Korikote, where they learnt all the news of Malabar; at this time [25r.] they did not trade, but returned again to their own Country Portugal, it is supposed the motive of their coming was for pepper - Two years afterwards they returned from Portugal with six ships, and came to Korikote, they landed, and while they were trading in a merchant like manner, the Fringies said to the Tamoory's Karrigars ${ }^{13}$; if you will put a stop to the trade of the Arabs, and Mappillas $^{14}$, we will give more money to the Sircar ${ }^{15}$, than they do, during this time, the Mappillas and Fringies quarrelled, and came to blows, the Rajah ordered some of his people to go and put a stop to it; the Fringies quarrelled with them too, and 70 of their people were killed in the affray, all the rest went on board their ships, and fired their large guns at those assembled on the shore, they in return fired at them, it continued for a short time, and the whole of the ships then sailed for Cochin, where they landed, saw the Rajah of [26r.] of the country, built a fort there; this was the first Fringy fort that was built in Malabar. There was at the time a Pally ${ }^{16}$ there which the Fringies pulled down, and destroyed; these people remained at Cochin, and carried on the business of merchants in a proper manner, they then went to Kananoor, lived among the people there in a peaceable manner, and built a fort, they carried on divers kinds of merchandize, bought pepper, some of them went to Portugal, the cause of their coming from, and returning to such a distance was supposed to be for pepper A year after this four ships came from Portugal, they landed at Cochin, and Kananoor, where they bought pepper and ginger, again they went home At the expiration of two years 28 [MS " 20 "] ships came from Portugal, they again returned with pepper, ginger, and divers other goods, at this period the Tamoory Rajah went against the Cochin Rajah and captured the other's Kowlgum ${ }^{17}$, during the war three of the Cochin Rajah's were killed, and the Tamoory having conquered the Cochin country [27r.] went to Korikote: a year after this period 10 ships came,

\footnotetext{
${ }^{9}$ Fringy a vulgar name for a European chiefly confined to the Portuguese.

${ }^{10}$ The term by which the Mussulmans of Malabar signify the Hegira.

${ }^{11} 672$ Malabar style of which the year 980 commenced $14^{\text {th }}$ September 1804 [the Malayalam calendar, or Kollavarsham, begins with the year $825 \mathrm{CE}$; in its chronology, the year 672 corresponds to $1498 \mathrm{CE}$, or 904 AH.]

12 a Place 2 M.s Sth. of Koilandy, and 13 North of Calicut.

${ }^{13}$ Karrigar is the Malabar term for a Minister of Government.

${ }^{14}$ Mappilla is the name given to those Mussulmans descendants of Arabs who are settled in Malabar.

${ }^{15}$ Sircar means Government.

${ }^{16}$ Pally is the name for the Mappilla place of worship [viz., a mosque].

${ }^{17}$ Kowlgum means Palace.
} 
seven of them fresh ships, and three of them belonging to the former 28 [ $\mathrm{MS}_{1}$ " 20 "] which after setting off, put back again, the seven fresh ships took in their lading of goods at Cochin and went away, the other three remained there, on hearing this, the Tamoory Rajah set off to Cochin with 100,000 Nayrs ${ }^{18}$, and several Mappillas for the purpose of seizing these ships, but a very great firing was kept up, and at that time they could not get into Cochin, after this the Ponanywaikel Mappillas fitted out three vessels, embarked on them, and sailed to where those ships were, a battle took place between them, many of the Mappillas having been killed they retreated; the next day the Ponanywaikel people and the Baliangaât people together fitted out four vessels, the people of Kappata, and those of Kollom fitted out three, together seven vessels on which the Mappillas embarked, and had a severe engagement with the Fringies in which they suffered no defeat; but as the rains were near the Tamoory withdrew his people to Calicut [sic]. [28r.] On Thursday the $22^{\text {nd }}$ of the Month Metha in the year of the Talika 915 or 683 Malabar style the Fringies came to Korikote, entered the town, burnt the Miskala Pally [i.e., Nākhudā Mithqāl Masjid], got into the Tamoory's Kowlgum and there took up their abode; at this time, the Tamoory Rajah was absent on a war against a distant country; the whole of the Nayrs about Korikote assembled together, attacked the Fringies and drove them from the Kowlgum, in which action the latter lost 500 Men killed, the rest of them embarked on their vessels and went away - Once before the above date the Fringies disembarked from their ships at Ponany $^{19}$, and of the vessels laid up there, they burnt 50 and killed seventy Mappillas: after this the Fringies sailed for Tekè Kollam, had an interview with the Rajah, addressed him respectfully, and built a fort there; nor did they procure any where so much pepper as at Cochin and Tekè Kollam which was the reason of their erecting the fort. - After this the Fringies went to Goa and captured it, at which period Goa belonged to Adil Shah Sultaun, the Fringies then made it the prin $=[29 r$. $]=$ cipal place of their residence for the transaction of all their affairs in Malabar - Adil Shah Saltaun attacked the Fringies, and retook Goa, but they returned in great force and a second time carried it, they then built several forts in that country, collected their forces, and the power of the Fringies from that time encreased daily, at which period they, and the Tamoory Rajah had some friendly conferences together and made peace - The cause of this was that from the time of the former quarrel the trade of the Mappillas decreased, and the person who was then Tamoory had been some time dead and the Elia Rajah ${ }^{20}$ had succeeded, who considered that it might be good policy to be at peace with the Fringies, that it would cause both his City, and the trade of the Mappillas to flourish in the same way that the traffic of Cochin and Kananoor did, that on these conditions if their differences were made up it would be beneficial to Korikote. - In this treaty an article was inserted by the Tamoory, that the Mappillas in his Dominions should every year load four vessels with ginger and pepper and sail for Mecca without any hindrance given [30r.] by the

\footnotetext{
${ }^{18}$ Nayrs are the hereditary soldiery of Malabar.

${ }^{19}$ Ponany is a large Mappilla town on the sea Coast, so called from Pon, or Poon Gold and Anè a nail.

${ }^{20}$ Elia means second.
} 
Fringis, to which the latter assented, and when the Fringis began the building of the fort, the Mappillas commenced their voyage for Arabia with the four ships, they sailed under the flag and passport of the Fringis, this was the year of the Talika 921 or 689 Malabar style, the above vessels disposed of their Cargoes, and returned again to Korikote at which time the Fringis had finished the fort, after which they would not permit the pepper and ginger to be carried to $M e c c a$, but prevented every other power from trading in these or any other articles except themselves; and they declared if they saw a root of ginger or a grain of pepper embarked on any other person's vessel they would seize and detain such vessel with all its cargo. - They then began to consider how to seize, and carry off the Tamury Raja, but their deceit did not succeed; this was the manner of planning it, after they had finished the fort and rendered it strong, they built a house near it for the residence of the rajah, some of the Fringis waited on the Tamoory, and told him that the king of Portugal had sent him a present, and that he must come there to receive it, he accordingly went, and while residing there, one of [31r.] the Fringies came, and informed him of the deception intended, immediately on hearing this, the Rajah said I am going to the tank, and will return again immediately, by which means he effected his escape. - The Fringy who had given this information to the Rajah, was sent by his Comrades to Kananoor. - The Fringies now began to kill the Nayrs and to force the Mappillas from their abodes, on which all the latter withdrew from the Coast, and assembled together eastward among the Mappillas living in Cochin, of the Moopanmar ${ }^{21}$, Ahamatha Marcar, Kunhaly Marcar, and Aly Marcar these three men set off from Cochin together with their followers they came to Korikote, had an interview with the Rajah, on which the Fringies considered them as intending to act inimically against them, they collected warlike stores, set off from Cochin, came to Ponanywaikel, they landed there, destroyed the houses, burnt some of the Pally, they cut down the Coco Nut trees growing by the sea side, killed some of the people, they staid there one day after this, and the next night they sailed for [32r.] Pandrany Kollom, where they seized all who had come to trade, and forty of their vessels, some of the people there were also killed; in this manner did they devastate the country, \& rendered it impossible for the inhabitants to reside in their abodes; on which the Tamoory prepared to go to war with them, but as he was himself absent at the time from Korikote, he sent his royal writing to his Karriayar Eliatha ${ }^{22}$ to get ready: on seeing the royal writing, he immediately began to collect warlike stores, and the Mappillas from several countries assembled, and came to Korikote, by which time the Tamoory Rajah also arrived: immediately the war began, many days having expired, and the provisions in the fort being expended, and not having it in their power to get a Supply, they embarked all their property on their ships, destroyed the fort, and unknown to those on the outside they got to their ships and went away; this was on the $16^{\text {th }}$ day of the Month Mahasannam in the year of the Talika 933 or 701 Malabar style; in this war two thousand Nayrs and Mappillas died — In consequence

\footnotetext{
${ }^{21}$ Moopa signifies a head or principal person, Moopanmar is plural.

${ }^{22}$ Eliatha is second, his second Minister in point of rank.
} 
of this the Tamoory, and the Fringie were [33r.] much exasperated against each other, and in a short time the Mappillas having repaired their vessels, they began to embark ginger, pepper, and other articles of trade for Guzzerat, and other countries, they now sailed without either flag or passport, some of their vessels the Fringies seized, since they drove ashore by means of firing at them, and others arrived at their destined ports and traded without molestation. - After the Monsoon of the above year, the Mappillas of Durmapatnam and their friends made peace with the Fringies, sailed under their flag and passport; the Tamoory, his subjects and the Fringies had now been long at variance, when in the year of the Talika 935 or 703 Malabar style, the Fringies went in a ship to Tanore and having landed there, had an interview with the Rajah, the Tamoory on hearing this sent his royal commands to the Tanore Rajah to send him all the men and property belonging to the ship, with which however he did not comply, but cultivated great friendship with the fringies [sic], they consulted together to perpower [overpower?] the Tamoory, plunder the Mappillas, destroy Ponanywaikel, and built a fort on the left side of the river at that place, for which purpose, [34r.] stones, Chunam, and other requisite articles were embarked in Vessels, and when arrived close to Ponanywaikel, a violent storm arose, and all of them except a small Dow were wrecked on the shore, some of the crews were drowned, and those who got on shore were made prisoners, the cannon that were in these ships the Tamoory got, their scheme of building a fort at Ponany was now rendered abortive; after this it is said that the Fringies built a fort at Chaliutt [Chaliyam] - A Captain came to Ponanywaikel in order to make peace with the Tamoory, he was a person who was acquainted with all that had passed at Korikote and Ponanywaikel the Tanore Rajah exerted himself greatly to bring about a peace between the Tamoory and the Fringies, the present Tamoory was the same who reigned when the fort at Korikote was taken from the Fringies; the Tanore Rajah came to Korikote, settled all disputes between the Tamoory and the Fringies, the latter were permitted to build a fort at Chaliutt. - The spot assigned for building the fort was on the public highway which being known it was considered as giving trouble to the lading of goods on vessels for Arabia, still leave was given to build [35r.] it at Chaliutt. - The Fringies began to collect materials for constructing their fort, and brought them into the river, this was in the year of the Talika 938, or the $5^{\text {th }}$ of Wrischigom 707 Malabar Style, the Fringies then finished the fort at Chaliutt, it was a very large one, and remarkably handsome. - During the building of the fort a Fringy having taken a stone from the Pally built by Mallikadeen ${ }^{23}$ the whole of the Mappillas of the place went to the Captain of the fort and having made their complaint, the Captain himself and his people took the stone and Chunam, went to the Pally, and had it repaired, this pleased the Mappillas very much. - The next day several of the Fringies went to the Pally, pulled down all the stones of it and carried them away, the whole of the Mappillas went a second time, and laid their complaint before the Captain, he told them that their Rajah had given

\footnotetext{
${ }^{23}$ The name of an Arab who is said to have converted the Emperor Perumal, and whose memory is held in great veneration by the Mappillas.
} 
both the Pally, and the ground to him, therefore he had pulled it down, on this the Mappillas retired overwhelmed with grief, and [36r.] at a little distance from thence they built another, after this the Fringies carried away the stones from the Mappilla burying ground for their fort. - The Elia Rajah having been installed Tamoory, a war began with the Chaliutt Rajah to destroy his country, but the latter having laid his grief submissively before the former, he withdrew his army, and then turned his forces against the Rajah of Tanore, while he was meditating an attack, the Tanore Rajah surrendered Karakatirutty, and new Ponany to him, on which they made peace, and the Tamoory retired. - In the year of the Talika 963 [MS “"957"] or 726 Malabar Style the Fringies burnt and destroyed Tricody, Pandrany Kollom, and Ponanywaikel. - In the year of the Talika 963 or 732 Malabar Style they Fringies and the Rajah made peace, they again quarrelled in $970 \mathrm{~T}$-or 736 M.S. $\left[\mathrm{MS}_{1}\right.$ "739," corrected to "736"] — The Fringies built forts at Mangalore and Pakanoor. In 970 T. or 739 M. Style a Mappilla called Kuty Poker Marcar ${ }^{24}$ cap $=[37 r$. $]=$ tured a ship belonging to the Fringies. - In 974 T. or 743 M.S. the Tamoory set off to wage war with Cochin and having tarried two months on the road, he lost 2000 Men by the water being poisoned, which obliged him to retire to Paloly and having placed the Tanore Rajah in the place he resided, the Tamoory went secretly away, the Fringies came to seize him, and did carry off the Tanore Rajah, so that had the latter not been placed there, they would have seized the Tamoory. In 979 T. or 747 M.S. the Tamoory took the fort at Chaliutt from the Fringies. - In 992 T. or 760 M.S. the Tamoory agreeing to their building a fort at Ponanywaikel, the Fringies, and him, made peace. — In 998 T. or $766 \mathrm{Mlbr}$. Style the Fringies seized a vessel of the Rajah's at sea in consequence of which they again quarrelled. - This is the History of the Fringies and the Rajah.

[Inserted in a different hand:]

The Brab tree MS. from which the foregoing was translated was presented to an English gentleman by the Vencaticota [original: Venkatycotta] Raja who is of the Tamuri family.

John $\mathrm{W}^{\mathrm{m}}$ Wye.

$19^{\text {th }}$ August 1800.

[In pencil, only in $\mathrm{MS}_{2}$ :] (Copy made in the Hon.ble Company's Library from Mr Wye's original translation)

\section{Bibliography}

\section{Unpublished primary sources}

British Library, London

- India Office Records, Bombay Despatches.

- India Office Records, Bombay Political and Secret Proceedings.

- India Office Records, Bombay Revenue Proceedings.

- India Office Records, Madras Revenue Proceedings.

\footnotetext{
${ }^{24}$ A descendant of this Mappilla by name of Kunhaly Marcar is now (1800) living at Cotta, the fact of taking the Vessel is still preserved in the family and they pride themselves much on it.
} 
- India Office Records, MSS. Eur.K.194 and K.195: Wye, "Translation of a History of the Portuguese landing in India, written on the leaves of the Brab tree (called Ola) in the Malabar language."

- India Office Records, MS. Islamic 2807d: Anonymous, "Qiș̣at shakarwatī farmāọ."

- India Office Records, MS. Islamic 2807f: Muḥammad al-Kalīkūtī, "Al-fatḥ al-mubīn li'l-sāmurī alladhī juhịbb al-muslimīn."

- India Office Records, MS. Islamic 2807e: Zayn al-Dīn al-Malabarī, "Tuḩfat al-mujāhidīn fi ba'ḍ akhbār al-purtukālīn.”

\section{Published primary sources}

Ames, G. J., ed. and trans. Em nome de Deus: The Journal of the First Voyage of Vasco da Gama to India, 1497-1499. Leiden: Brill, 2009.

Buchanan, F. A Journey from Madras through the Countries of Mysore, Canara and Malabar. 3 vols. London, 1807.

Camões, Luiz Vaz de. The Lusíads. Translated by W. J. Mickle. 5th ed. London, 1877.

Castro, X. de, ed. Voyage de Pyrard de Laval aux Indes orientales (1601-1611). 2 vols. Paris: Chandeigne, 1998.

Correia, G. Lendas da Índia. Edited by R. J. de Lima Felner. 8 vols. Lisbon, 1858-66.

Defrémery, C., and B. R. Sanguinetti, eds. and trans. Voyages d'Ibn Batoutah, texte arabe, accompagné d'une traduction. 4 vols. Paris, 1853-58.

Duarte Barbosa. O Livro de Duarte Barbosa: Edição Crítico e Anotada. Edited by M. A. da Veiga e Sousa. 2 vols. Lisbon: Instituto de Investigação Científica Tropical, 1996-2000.

Goitein, S. D., and M. A. Friedman, eds. and trans. India Traders of the Middle Ages: Documents from the Cairo Geniza ("India Book"). Leiden: Brill, 2008.

Kurup, K.K.N. "Foreword." In Shaykh Zainuddin Makhdum's Tuhfat al-Mujāhidīn: A Historical Epic of the Sixteenth Century. Translated by S. M. H. Nainar. Kuala Lumpur: Islamic Book Trust, 2006.

- ed. Koodali Granthavari. Calicut: University of Calicut, 1995.

Logan, W., ed. A Collection of Treaties, Engagements and other Papers of Importance relating to British Affairs in Malabar. 2 vols. Calicut, 1879.

Lopes, D., ed. and trans. Historia dos Portugueses no Malabar por Zinadim: Manuscripto Arabe do Seculo XVI. Lisbon, 1898.

Menon, T. M., trans. Keralolpatti by Gundert: Translation into English. Thiruvananthapuram: International School of Dravidian Linguistics, 2003.

Nainar, S. M. H., trans. "Tuḥfat-al-Mujāhidīn, An Historical Work in the Arabic Language." Annals of Oriental Research (University of Madras) 6:1-2 (1941-42).

Narayanan, M. G. S., ed. Vanjery Granthavari. Calicut: University of Calicut, 1987.

State Archives Department, Government of Kerala. A Translation of a Record-Grandhavari in the State Archives. Trivandrum: Government Press, 1973.

\section{Secondary sources}

Bouchon, G. "Le Musulmans du Kerala à l'époque de la découverte Portugaise." Mare Luso-Indicum 2 (1973): 3-59.

Boxer, C. R. "Some Remarks on the Value of Portuguese Sources for Asian History, Sixteenth to Eighteenth Centuries." Portuguese Studies 1 (1984-85): 193-203.

Dagnall, H. "British Watermarks: Dates in Watermarks." The Quarterly: Review of the British Association of Paper Historians 21 (1997): 22.

Dale, S. F. "Trade, Conversion and the Growth of the Islamic Community of Kerala, South India." Studia Islamica 71 (1990): 155-75. 
Das Gupta, A. "Indian Merchants and the Western Indian Ocean: The Early Seventeenth Century." Modern Asian Studies 19:3 (1985): 481-99.

Eaton, R. M. The Sufis of Bijapur, 1300-1700: Social Roles of Sufis in Medieval India. Princeton: Princeton University Press, 1978.

Fonseca, Luís Adão da. Vasco da Gama: o Homem, a Viagem, a Época. Lisbon: Comissariado da Exposição Mundial de Lisboa de 1998, 1997.

Haridas, V. V. "Legitimation in a Little Kingdom: The Use of History in the Kingdom of Kozhikode." Indica 46:1 (2009): 71-78.

—. "Symbols and Status of Local Magnates in the Kingdom of Khôzhikôde: A Study of 'The Sword and the Robe' Ceremony." Indica 39:2 (2002): 129-44.

Ho, E. "Custom and Conversion in Malabar: Zayn al-Din al-Malibari's Gift of the Mujahidin: Some Accounts of the Portuguese." In Islam in South Asia in Practice, edited by B. D. Metcalf. Princeton: Princeton University Press, 2009.

Hobson, J. M. The Eastern Origins of Western Civilisation. Cambridge: Cambridge University Press, 2004.

Logan, W. Malabar Manual, Edited by P. J. Cherian, 2 vols. Thiruvananthapuram: Kerala Gazetteers Department, 2000.

Malekandathil, P. Portuguese Cochin and the Maritime Trade of India, 1500-1663. New Delhi: Manohar, 2001.

Malieckal, B. "Muslims, Matriliny, and A Midsummer Night's Dream: European Encounters with the Mappilas of Malabar, India." Muslim World 95:2 (2005): 297-316.

Mathew, K. S. History of the Portuguese Navigation in India (1497-1600). Delhi: Mittal, 1988.

—. Maritime Trade of the Malabar Coast and the Portuguese in the Sixteenth Century. Revd. ed. New Delhi: Manohar, 2016.

Nambiar, O. K. The Kunjalis: Admirals of Calicut. London: Asia Publishing House, 1963.

Nampoodiri, N. M. "Cultural Tradition in Medieval Kerala." In Perspectives on Kerala History: The Second Millennium, edited by P. J. Cherian. Trivandrum: Kerala State Gazetteer, 1999.

Narayanan, M. G. S. Perumāls of Kerala: Brahmin Oligarchy and Ritual Monarchy: Political and Social Conditions of Kerala under the Cèra Perumāls of Makōtai (c. AD 800-AD 1124). Thrissur: Cosmo Books, 2013.

Newitt, M. A History of Portuguese Overseas Expansion, 1400-1668. London: Routledge, 2005.

O'Rourke, K. H. and J. G. Williamson. "Did Vasco da Gama Matter for European Markets?" Economic History Review 62:3 (2009): 655-84.

Panikkar, K. M. Asia and Western Dominance: A Survey of the Vasco Da Gama Epoch of Asian History, 1498-1945. London: Allen \& Unwin, 1959.

—. Malabar and the Portuguese. 1929. Reprint New Delhi: Voice of India, 1997.

Pearson, M. N. Coastal Western India: Studies from the Portuguese Records. New Delhi: Concept, 1981.

—. The Portuguese in India. Cambridge: Cambridge University Press, 1987.

Perrett, R. W. "History, Time, and Knowledge in Ancient India." History and Theory 38:3 (1999): 307-21.

Prange, S. R. "'Measuring by the Bushel': Reweighing the Indian Ocean Pepper Trade." Historical Research 84:224 (2011): 212-35.

—. "A Trade of No Dishonor: Piracy, Commerce, and Community in the Western Indian Ocean, Twelfth to Sixteenth Century." American Historical Review 116:5 (2011): 1269-93.

Rao, V. N., D. Shulman and S. Subrahmanyam. Textures of Time: Writing History in South India, 1600-1800. New York: Other Press, 2003. 
Shokoohy, M. Muslim Architecture of South India: The Sultanate of Ma'bar and the Traditions of Maritime Settlers on the Malabar and Coromandel Coasts (Tamil Nadu, Kerala and Goa). London: Routledge Curzon, 2003.

Subrahmanyam, S. The Career and Legend of Vasco da Gama. Cambridge: Cambridge University Press, 1998.

- The Portuguese Empire in Asia, 1500-1700: A Political and Economic History, 2nd ed. Oxford: Wiley-Blackwell, 2012.

Subramanian, L. "Of Pirates and Potentates: Maritime Jurisdiction and the Construction of Piracy in the Indian Ocean." UTS Review 6:2 (2000): 14-23.

Veluthat, K. The Early Medieval in South India. Oxford: Oxford University Press, 2008.

—. "History in the Construction of a Regional Identity: Kerala and The Kēralōlpatti." In Medieval India: Problems and Possibilities (Essays in Honour of Professor A. R. Kulkarni), edited by Radhika Seshan. New Delhi: Rawat Publications, 2006.

Wood, C. "The First Moplah Rebellion against British Rule in Malabar." Modern Asian Studies 10:4 (1976): 543-56.

Yule, H. and A. C. Burnell. Hobson-Jobson: A Glossary of Colloquial Anglo-Indian Words and Phrases. London: Murray, 1903.

\section{Notes}

* Sebastian Prange is Assistant Professor of South Asian History at the University of British Columbia. He has published on the history of Islam, commerce, and piracy in the Indian Ocean. His forthcoming book, Monsoon Islam: Trade \& Faith on the medieval Malabar Coast, studies the organization and transoceanic connections of Muslim communities in premodern South India. He gratefully acknowledges the support of the Social Sciences and Humanities Research Council of Canada (Insight Development Grant 430-2014-00190) as well as research assistance by Leyla SaftaZecheria, Natalia Damasceno, and Hanna Smyth. He would further like to thank the journal's editors and anonymous reviewers for their helpful comments and suggestions.

1 Camões, Lusíads, canto 7:64.

2 Panikkar, Asia and Western Dominance. As a counterpoint, see Hobson, Eastern Origins of Western Civilisation, chap. 7.

3 O'Rourke and Williamson, "Did Vasco da Gama Matter," 655-84; Das Gupta, "Indian Merchants and the Western Indian Ocean," 484.

4 Pearson, The Portuguese in India, 3.
5 This is not to say that the Portuguese records are perfect; especially for Vasco da Gama's first voyage they are quite problematic in their own right. See Pearson, Coastal Western India; and Boxer, "Some Remarks on the Value of Portuguese Sources," Fonseca.

6 Ames, Em nome de Deus, 69. Also see Subrahmanyam, The Career and Legend of Vasco da Gama, 120.

7 Ibn Bațtūța, for instance, who had travelled across maritime Asia, described Calicut as one of the largest ports in the world, visited by merchants from China, Java, Ceylon, the Maldives, Yemen, and Persia. See Defrémery and Sanguinetti, Voyages d'Ibn Batoutah, 4.88-89.

8 See, for instance, Prange, "Reweighing the Indian Ocean Pepper Trade," 212-35.

9 Subramanian, "Of Pirates and Potentates," 43.

10 This point is reflected, for instance, in the abundant bibliography of an authoritative study of the sixteenth-century Malabar Coast, which among the dozens of primary sources consulted lists only three of non-European provenance. Mathew, Maritime Trade of the Malabar Coast, 383-406. 
11 British Library, India Office Records, MS. Islamic 2807e: Zayn al-Dīn alMalabarī, "Tuhfat al-mujāhidīn fi ba'ḍ akhbār al-purtukālīn." Arabic edition and Portuguese translation in Lopes, Historia dos Portugueses no Malabar por Zinadim; English translation in Nainar, "Tuḥfat-al-Mujāhidīn."

12 Cited in Rao, Shulman, and Subrahmanyam, Textures of Time, 1.

13 Perrett, "History, Time, and Knowledge in Ancient India," 307.

14 Rao, Shulman, and Subrahmanyam, Textures of Time.

15 Sousa, $O$ Livro de Duarte Barbosa, 2.127-28.

16 Castro, Voyage de Pyrard de Laval, 380-81.

17 The city of Calicut suffered especially severely, having been pillaged twice in the course of the Mysorean Wars in 1773 and 1788 .

18 See, for instance, Goitein and Friedman, India Traders of the Middle Ages, 60-61.

19 Sousa, O Livro de Duarte Barbosa, 2.128.

20 Castro, Voyage de Pyrard de Laval, 376, 381. Also see also see Yule and Burnell, Hobson-Jobson, s.v. "Ollah," 636.

21 Cambridge University Library, MS Add.1049.1: "Pārameśvaratantra."

22 The Wye manuscript is not referred to in any of the studies cited in the bibliography. The only exception is an article by Bindu Malieckal, a scholar of English literature. Regrettably, Professor Malieckal can no longer reconstruct the circumstances of her first encounter with this manuscript (personal communication). Malieckal, "Muslims, Matriliny, and A Midsummer Night's Dream," $314 n 47$.

23 British Library, India Office Records, MSS. Eur.K.194 and K.195: Wye, "Translation of a History of the Portuguese landing in India, written on the leaves of the Brab tree (called Ola) in the Malabar language."

24 Portal \& Co supplied the Bank of England with its banknote paper from 1725 , and its products are frequently encountered in East India Company correspondence. That the paper bears such a convenient sign of its year of production is due to short-lived legislation, which between the years 1794 to 1811 made it compulsory to include the year in the watermark; see Dagnall, "British Watermarks," 22.

25 British Library, India Office Records, Bombay Despatches: XII, E/4/1007, 173, 223.

26 Logan, Collection of Treaties, doc. 88, vol. 1.27.

27 British Library, India Office Records, Bombay Despatches: XVI, E/4/1011, 415-16.

28 British Library, India Office Records, Bombay Despatches: XXIV, E/4/ 1019, 786.

29 British Library, India Office Records, Bombay Revenue Proceedings: 16 October 1798, P366/23, 1590; Bombay Political and Secret Proceedings: 28 September 1798, P/380/74, 5215; "Considerations on Mappila disturbances by Wye, Malabar Translator," enclosed in Report of Major Walker, 5 February 1800, P/381/13, 3343-44; Bombay Political and Secret Proceedings, 25 February 1800, P/381/10, 1287-88; Madras Revenue Proceedings, 20 February 1801, P/275/45, 176, 184.

30 Buchanan, Journey from Madras, 2.434-35.

31 See Wood, "First Moplah Rebellion," $544 \mathrm{n} 3$.

32 Logan, Malabar Manual, 496n2. For an English translation, see Menon, Keralolpatti by Gundert. For discussions of the text, see, for instance, Veluthat, Early Medieval in South India, ch. 6, and Haridas, "Legitimation in a Little Kingdom," 71-78.

33 See Narayanan, Vanjery Granthavari; and Kurup, Koodali Granthavari.

34 A pioneering examination of these records is Nampoodiri, "Cultural Tradition in Medieval Kerala," in Cherian, Perspectives on Kerala History, 265-325. More recently, these materials have been 
subjected to further study in Haridas, "Symbols and Status," 129n2.

35 State Archives Department, Government of Kerala. A Translation of a RecordGrandhavari.

36 Logan, Manual, 244; and Narayanan, Perumāls, 20.

37 See Veluthat, "History in the Construction of Regional Identity," 83-85.

38 This version was the one edited and translated by the German missionary and scholar Hermann Gundert. It has formed the basis of most subsequent studies. See Menon, Keralolpatti.

39 The fullest version of the Cheraman Perumal legend in any language is found in a little-known Arabic manuscript; British Library, India Office Records, MS. Islamic 2807d: Anonymous, "Qișșat shakarwatī farmāụ."

40 The date of composition of this text is discussed below.

41 Zayn al-Dīn al-Malabarī, "Tuḥfat al-mujāhidīn," fol. 113v.

42 Zayn al-Dīn al-Malabarī, "Tuḥfat al-mujāhidīn," fol. 115v.

43 Zayn al-Dīn al-Malabarī, "Tuhfat al-mujāhidīn," fol. 113r-113v.

44 See for instance Eaton, Sufis of Bijapur, 83.

45 See for instance Ho, "Custom and Conversion in Malabar," 403; Dale, "Trade, Conversion and the Growth of the Islamic Community of Kerala," 162; and Kurup, "Foreword," xvii. Mehrdad Shokoohy suggests that local records offer $1574 / 75$ as an alternative date of composition, but this in fact refers to a different book, Fath al-mu'ìn, by the same author; Shokoohy, Islamic Architecture, 241.

46 Logan, Manual, 333.

47 Panikkar, Malabar and the Portuguese, 134-35.
48 British Library, Wye $\mathrm{MS}_{2}$, fol. 37r. "979 T." refers to the Islamic calendar; according to Wye $\left(\mathrm{MS}_{2}\right.$, fol. 24r) "Talika" is the term by which the Mappilas designated the Hegira. It corresponds to May 1571 to May 1572 - the Portuguese surrendered Chaliyam fort on 15 September 1571. "747 M.S." stands for "Malabar Style," that is the calendar according to the Malayalam (or Kollam) era that began in 825 , which corresponds to 1572 .

49 Elsewhere in the narrative, a Zamorin is succeeded by the "Elia Rajah," that is by a younger prince. British Library, Wye $\mathrm{MS}_{2}$, fols. 29r, 32r. The author is grateful to Rosily Poovelil Mayer for confirming the Malayalam usage.

50 Zayn al-Dīn al-Malabarī, "Tuhfat almujāhidīn," fol. 136r.

51 The author is grateful to Itinerario associate editor Gijs Kruijtzer for suggesting this line of argument.

52 British Library, India Office Records, MS. Islamic 2807f: Muhammad al-Kalīkūtī, "Al-fatḥ al-mubīn li'l-sāmurī alladhī juhibb al-muslimīn."

53 On the development of Muslim naval power, and their evolving political profile, across the sixteenth century, see for instance Nambiar, The Kunjalis; Bouchon, "Le Musulmans du Kerala"; and Prange, "A Trade of No Dishonor."

54 The overall narrative corresponds to the chronology found in the standard Portuguese chronicles, such as Correia's Lendas da Índia (1551-60). Cf. Panikkar, Malabar and the Portuguese; Pearson, Portuguese in India; Mathew, History of the Portuguese Navigation in India; Malekandathil, Portuguese Cochin and the Maritime Trade of India; Newitt, History of Portuguese Overseas Expansion; and Subrahmanyam, Portuguese Empire in Asia. 